\title{
Erratum to: On the Correlation Between Mechanical Degradation of Lubricating Grease and Entropy
}

\author{
Asghar Rezasoltani • M. M. Khonsari
}

Published online: 11 March 2015

(c) Springer Science+Business Media New York 2015

Erratum to: Tribol Lett (2014) 56:197-204

DOI 10.1007/s11249-014-0399-8

Unfortunately, there was a typographical error in the original publication of the article in Section "3.2.2 Penetration Test Procedure." The correct value of the normal force used in all the penetration tests is $2 \mathrm{~N}$ and not $50 \mathrm{~N}$.

The online version of the original article can be found under doi:10.1007/s11249-014-0399-8.

\footnotetext{
A. Rezasoltani · M. M. Khonsari ( $\square)$

Department of Mechanical and Industrial Engineering, Louisiana

State University, 2508 Patrick Taylor Hall, Baton Rouge,

LA 70803, USA

e-mail: Khonsari@me.lsu.edu; mkhonsari@laregents.org
} 